LIVER DISEASE

\title{
Enhanced vasodilatation to endothelin antagonism in patients with compensated cirrhosis and the role of nitric oxide
}

\author{
A Helmy, D E Newby, R Jalan, P C Hayes, D J Webb
}

Gut 2003;52:410-415

\begin{abstract}
Background and aims: Patients with advanced cirrhosis have systemic vasodilatation and increased nitric oxide (NO) production despite activated vasopressor systems, including the endothelin system. The aims of this study were to assess the contribution of endogenous endothelin 1 (ET-1) and NO to the maintenance of basal forearm vascular tone in patients with preascitic cirrhosis $(n=7)$ and in age and sex matched healthy controls $(n=7)$.

Methods: Using venous occlusion plethysmography, forearm blood flow (FBF) responses to subsystemic locally active intra-arterial infusion of BQ-123 (a selective endothelin type $A$ receptor $\left(E_{A}\right.$ ) receptor antagonist; $10 \mathrm{nmol} / \mathrm{min}$ ) were measured before and during application of an "NO clamp": a balanced co- infusion of $\mathrm{L}-\mathrm{N}^{G}$-monomethyl-arginine (a selective $\mathrm{NO}$ synthase inhibitor) and sodium nitroprusside (an exogenous NO donor) to block endogenous NO production and restore $\mathrm{NO}$ mediated basal FBF, respectively.

Results: L-NMMA infusion produced a reduction in FBF $(p<0.001)$ which was similar in both groups Before applying the "NO clamp", BQ-123 caused an increase in FBF in both groups $(p<0.001)$ that was greater in patients with cirrhosis $(p<0.01)$. During the "NO clamp", BQ-123 induced vasodilatation was abolished in controls and attenuated in patients $(p<0.001)$ but remained significantly greater in patients with cirrhosis ( $\mathrm{p}<0.01$ ).

Conclusions: These findings indicate a greater $\mathrm{ET}_{\mathrm{A}}$ mediated contribution of endogenous $\mathrm{ET}-1$ to the maintenance of basal forearm vascular tone in patients with preascitic cirrhosis. In addition, enhanced vasodilatation to $\mathrm{ET}_{\mathrm{A}}$ receptor antagonism in cirrhosis cannot be entirely attributed to $\mathrm{NO}$ release but is likely to be related to reversal of direct ET-1 mediated tone.
\end{abstract}

See end of article for

Accepted for publication 20 September 2002

$\mathrm{P}$ atients with cirrhosis exhibit a hyperdynamic circulation characterised by a high cardiac output, hypervolaemia, a low systemic vascular resistance, and an increased portal pressure ${ }^{1-3}$ that worsens with disease severity. ${ }^{4}$ This hyperdynamic circulation is due to systemic arteriolar dilatation which occurs despite the presence of activated vasopressor systems, including the renin-angiotensin and endothelin systems, and is believed to be responsible for the development of the complications of cirrhosis such as ascites, oesophageal varices, and hepatorenal syndrome. ${ }^{5}$ Therefore, a better understanding of the mechanism(s) underlying the systemic vasodilatation associated with cirrhosis is essential for the development of therapeutic, and possibly preventive, interventions.

Endothelin-1 (ET-1) is one of the most potent vasoconstrictors known, belonging to a 21 - amino acid peptide family with a range of biological effects. ${ }^{67}$ Molecular studies have, so far, identified two endothelin receptor subtypes in mammalian species: endothelin $\mathrm{A}\left(\mathrm{ET}_{\mathrm{A}}\right)^{7}$ and endothelin $\mathrm{B}\left(\mathrm{ET}_{\mathrm{B}}\right) .^{8}$ In vascular smooth muscle cells, both receptors are expressed ${ }^{7}$ and mediate vasoconstriction. ${ }^{9-11}$ ET- 1 induced vasoconstriction is predominantly mediated by the $\mathrm{ET}_{\mathrm{A}}$ receptor but $\mathrm{ET}_{\mathrm{B}}$ receptors may contribute under some circumstances. ${ }^{12} \mathrm{The}_{\mathrm{ET}}$ receptors are also found on endothelial cells where they cause vasodilatation through the release of endothelium derived vasodilators, including nitric oxide $(\mathrm{NO}) .{ }^{13}$ ET- 1 mediated vascular tone is therefore a balance between the constrictor and dilator effects mediated by these two receptors.

We and others have demonstrated that selective $\mathrm{ET}_{\mathrm{A}}$ receptor antagonism, using BQ-123, causes forearm vasodilatation in healthy humans, ${ }^{14-16}$ and that this response is principally mediated through NO generation. ${ }^{15}$ We have also shown that
BQ-123 infusion produces an enhanced forearm vasodilatation in patients with preascitic cirrhosis ${ }^{14}$ although the exact mechanism is unknown. Accumulating evidence for an increase in endothelium derived NO synthesis in patients with cirrhosis $^{17}$ suggests that endogenous NO release may, at least in part, contribute to the enhanced vasodilatation to $\mathrm{ET}_{\mathrm{A}}$ receptor antagonism.

Therefore, the aims of the present study, in patients with preascitic cirrhosis and healthy matched controls, were to assess the contribution of endogenous ET-l and NO to the maintenance of basal peripheral vascular tone, and to determine the relationship between $\mathrm{ET}_{\mathrm{A}}$ receptor antagonism and endogenous NO release.

\section{SUBJECTS AND METHODS Subjects}

Seven patients with biopsy proven cirrhosis and seven age and sex matched healthy volunteers were recruited. Patients were defined as preascitic if they had never had ascites according to clinical and ultrasonographic examinations. All patients were ambulant, had normal serum creatinine $(<100 \mu \mathrm{mol} / \mathrm{l})$, and endoscopically proven oesophageal varices. To avoid the depressive effect of ethanol on vascular responses, ${ }^{18}$ patients

Abbreviations: $\mathrm{ET}$ - 1, endothelin 1; ET receptor, endothelin type A receptor; $E T_{B}$ receptor, endothelin type $B$ receptor; $N O$, nitric oxide; L-NMMA, L-N $N^{G}$-monomethyl-arginine; eNOS, endothelial nitric oxide synthase; SNP, sodium nitroprusside; MAP, mean arterial pressure; HR heart rate; $\mathrm{FBF}$, forearm blood flow; $\mathrm{Cl}$, cardiac index; $\mathrm{SI}$, stroke index TPVRI, total peripheral vascular resistive index; BMI, body mass index. 
with alcoholic liver disease were abstinent from alcohol for at least one month, as confirmed by history and random blood ethanol testing. In addition, all subjects in both groups were allowed normal sodium intake $(\sim 150 \mathrm{mmol} /$ day $)$ to avoid the possibility of altering the activity of endogenous vasopressor systems. ${ }^{19}$ None of the subjects received vasoactive or non-steroidal anti- inflammatory drugs in the week before each study, and all subjects abstained from food, tobacco, and caffeine containing drinks for at least four hours prior to each study. Three subjects in each group were smokers of less than 10 cigarettes/day. All female subjects were post-menopausal, both for safety reasons and to avoid the variability in vascular responses that may be associated with cyclic hormonal changes.$^{20}$ Exclusion criteria included the presence of malignancy, encephalopathy, portosystemic shunting (surgical or TIPSS), or any significant cardiovascular disease such as diabetes mellitus, hypercholesterolaemia, or hypertension. Studies were undertaken with the approval of the local research ethics committee, the written informed consent of each subject, and in accordance with the Declaration of Helsinki ( 1989) of the World Medical Association.

\section{Intra-arterial administration and drugs}

The brachial artery of the non-dominant arm was cannulated using a 27 standard wire gauge steel needle (Cooper's Needle Works, Birmingham, UK) under local anaesthesia using $1 \%$ lignocaine (Xylocaine; Astra Pharmaceuticals Ltd, Kings Langley, UK). Needle patency was maintained by saline infusion via an IVAC P1000 syringe pump (IVAC Ltd, Basingstoke, UK) at a constant rate of $1 \mathrm{ml} / \mathrm{min}$. All drugs were dissolved in physiological saline $(0.9 \%$; Baxter Healthcare Ltd, Thetford, UK). Pharmaceutical grade BQ-123 (a selective ET receptor antagonist; Clinalfa AG, Läufelfingen, Switzerland) was infused at the locally active and subsystemic dose of $10 \mathrm{nmol} /$ min. ${ }^{21}$ With this dose, forearm blood flow (FBF) has been shown to plateau within 60 minutes of infusion. ${ }^{15}$ For the "NO clamp" (see below), L- $N^{\mathrm{G}}$-monomethyl-arginine (L-NMMA, a selective nitric oxide synthase (NOS) inhibitor; Clinalfa AG) at a dose of $4 \mu \mathrm{mol} / \mathrm{min}$, and sodium nitroprusside (SNP, an exogenous NO donor; David Bull Laboratories, Victoria, Australia) at titrated doses (80-600 ng/min) were used. This dose of L-NMMA has previously been shown to produce a maximal vasoconstrictor response in the forearm circulation. ${ }^{22}{ }^{23}$ Due to the light sensitivity of SNP, it was prepared and infused in syringes covered by opaque foil.

\section{Measurement of systemic haemodynamics}

Baseline cardiac function, including heart rate, stroke volume, and cardiac output, was measured using a non-invasive thoracic electrical bioimpedance method (BoMed NC-COM3; BoMed Medical Manufacturer Ltd, Irvine, California, USA), as described previously. ${ }^{24}{ }^{25}$ Cardiac index (CI), stroke index (SI), and total peripheral vascular resistive index (TPVRI) were calculated according to the formulae:

CI $\left(1 / \mathrm{min} / \mathrm{m}^{2}\right)=$ cardiac output $(1 / \mathrm{min}) /$ body surface area $\left(\mathrm{m}^{2}\right)$; SI $\left(\mathrm{ml} / \mathrm{m}^{2}\right)=$ stroke volume $(\mathrm{ml}) /$ body surface area $\left(\mathrm{m}^{2}\right)$; and TPVRI $\left(\mathrm{mm} \mathrm{Hg} / \mathrm{l} / \mathrm{min} / \mathrm{m}^{2}\right)=$ mean arterial pressure (MAP mm $\mathrm{Hg}) / \mathrm{CI}\left(\mathrm{l} / \mathrm{min} / \mathrm{m}^{2}\right)$.

Blood pressure and heart rate were measured in the control arm using a non-invasive oscillometric sphygmomanometer (Takeda UA 751; Takeda Medical Inc, Tokyo, Japan) at intervals throughout the study. ${ }^{26}$ MAP was calculated according to the formula: MAP $(\mathrm{mm} \mathrm{Hg})=$ diastolic arterial pressure $+1 / 3$ pulse pressure.

\section{Measurement of forearm blood flow (FBF)}

All studies were performed in a quiet temperature controlled room maintained at $22-24^{\circ} \mathrm{C}$. FBF was measured as described previously. ${ }^{14} 27$ Briefly, FBF measurements were made in both the infused and non-infused arms by venous occlusion plethysmography using mercury in Silastic strain gauges applied to the widest part of the forearm. Hands were placed above the level of the heart throughout the study period, and were excluded by rapid inflation of wrist cuffs to a pressure of 220 mm Hg using E20 Rapid Cuff Inflators (DE Hokanson Inc, Washington DC, USA). Upper arm cuffs were inflated to 40 $\mathrm{mm} \mathrm{Hg}$ for 10 seconds in every 15 seconds to achieve venous occlusion and obtain blood flow measurements.

\section{Study design}

Two protocols (fig l) were applied on two separate occasions one week apart and in random order. Before participating in each of the protocols, saline was infused for 30 minutes to allow time for equilibration, with FBF measurements being made in the last three minutes of every 10 minutes, and the final measure taken as the baseline FBF. In protocol 1, BQ-123 was infused at a dose of $10 \mathrm{nmol} / \mathrm{min}$ for 60 minutes during which FBF was measured for three minutes in every 10 minutes. In protocol 2, to assess the contribution of endogenous $\mathrm{NO}$ production to the forearm vascular responses of $\mathrm{ET}_{\mathrm{A}}$

\section{Protocol 1}

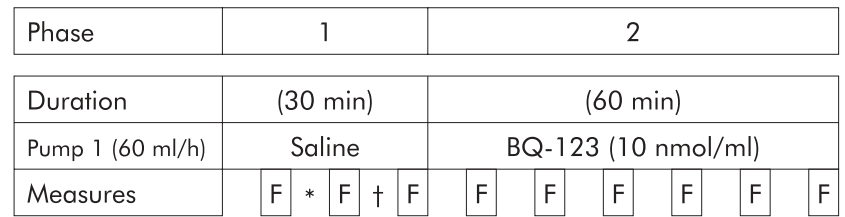

Protocol 2

\begin{tabular}{|c|c|c|c|c|c|c|c|c|c|c|c|c|c|c|c|}
\hline Phase & \multicolumn{3}{|c|}{1} & \multicolumn{2}{|c|}{2} & \multicolumn{4}{|c|}{3} & \multicolumn{6}{|c|}{4} \\
\hline Duration & \multicolumn{3}{|c|}{ (30 min) } & \multicolumn{2}{|c|}{ (20 min) } & \multicolumn{4}{|c|}{ Variable } & \multicolumn{6}{|c|}{$(60 \mathrm{~min})$} \\
\hline Pump $1(20 \mathrm{ml} / \mathrm{h})$ & \multicolumn{3}{|c|}{ Saline } & \multicolumn{2}{|c|}{ L-NMMA } & \multicolumn{4}{|c|}{ L-NMMA } & \multicolumn{6}{|c|}{ L-NMMA } \\
\hline Pump $2(20 \mathrm{ml} / \mathrm{h})$ & \multicolumn{3}{|c|}{ Saline } & \multicolumn{2}{|c|}{ Saline } & \multicolumn{4}{|c|}{ SNP } & \multicolumn{6}{|c|}{ SNP } \\
\hline Pump $3(20 \mathrm{ml} / \mathrm{h})$ & \multicolumn{3}{|c|}{ Saline } & \multicolumn{2}{|c|}{ Saline } & \multicolumn{4}{|c|}{ Saline } & \multicolumn{6}{|c|}{ BQ-1 $23(30 \mathrm{nmol} / \mathrm{ml})$} \\
\hline Measures & $\mathrm{F}$ & $\mathrm{F}$ & $\mathrm{F}$ & $\mathrm{F}$ & $\mathrm{F}$ & $\mathrm{F}$ & $\mathrm{F}$ & $F$ & $\mathrm{~F}$ & $\mathrm{~F}$ & $F$ & $\mathrm{~F}$ & $F$ & $\mathrm{~F}$ & $\mathrm{~F}$ \\
\hline
\end{tabular}

Figure 1 Schematic diagram of the study protocols. F=Bilateral forearm blood flow measurements each for three minutes. BQ- 123 was given at $10 \mathrm{nmol} / \mathrm{min}$. L- $N^{G}$-monomethyl-arginine (L-NMMA) was given at $4 \mathrm{umol} / \mathrm{min}$. Sodium nitroprusside (SNP) was given at titrated doses ranging from 80 to $600 \mathrm{ng} / \mathrm{min}$ to achieve a stable blood flow close to the baseline value. *Time for blood sampling; ttime for measuring vascular bioimpedance. 
Table 1 Characteristics of the subjects

\begin{tabular}{|c|c|c|c|c|}
\hline \multirow{2}{*}{$\begin{array}{l}\text { Variable } \\
\text { Age (y) }\end{array}$} & \multicolumn{2}{|c|}{$\begin{array}{l}\text { Patients with } \\
\text { cirrhosis }(n=7)\end{array}$} & \multicolumn{2}{|c|}{$\begin{array}{l}\text { Healthy controls } \\
(n=7)\end{array}$} \\
\hline & 53 & (5) & 52 & (5) \\
\hline $\operatorname{Sex}(M: F)$ & $3: 4$ & & $3: 4$ & \\
\hline Weight (kg) & 61 & $(4)^{*}$ & 75 & (4) \\
\hline Height $(\mathrm{cm})$ & 167 & (4) & 167 & (4) \\
\hline $\mathrm{BSA}\left(\mathrm{m}^{2}\right)$ & & $(0.1)$ & 1.8 & (0.1) \\
\hline BMI $\left(\mathrm{kg} / \mathrm{m}^{2}\right)$ & 22 & $(1)^{*}$ & 27 & (1) \\
\hline \multicolumn{5}{|l|}{ Liver disease aetiology } \\
\hline Primary biliary cirrhosis & 3 & & - & \\
\hline Hepatitis C virus & 1 & & - & \\
\hline Alcoholic liver disease & 2 & & - & \\
\hline Autoimmune $\mathrm{CAH}$ & 1 & & - & \\
\hline Child-pugh score & 6 & (1) & - & \\
\hline \multicolumn{5}{|l|}{ Child grade } \\
\hline A & 4 & & - & \\
\hline B & 3 & & - & \\
\hline Serum albumin (g/l) & 38 & (2) & 42 & (2) \\
\hline Serum bilirubin (mmol/l) & 28 & $(10)^{*}$ & 12 & (2) \\
\hline Prothombin time (s) & 11 & (1) & 11 & (0.4) \\
\hline Oesophageal varices & 7 & & - & \\
\hline
\end{tabular}

Results are expressed as mean (SEM).

$\mathrm{BMI}$, body mass index; $\mathrm{BSA}$, body surface area; $\mathrm{CAH}$, chronic active hepatitis.

${ }^{*} \mathrm{p}<0.05$ versus controls.

receptor blockade, endogenous NO synthesis was inhibited by the "NO clamp" as described previously. ${ }^{15} 29$ Briefly, L-NMMA was continuously infused at a rate of $4 \mu \mathrm{mol} / \mathrm{min}$ for $20 \mathrm{~min}$ utes to achieve maximal inhibition of local vascular endogenous NOS activity. Thereafter, SNP was co-infused at titrated doses until FBF had been restored to within $10 \%$ of baseline flow and was sustained for at least two consecutive FBF measurements. Once a stable baseline FBF was obtained, the "NO clamp" was continued with these doses of L-NMMA and SNP, and then BQ-123 (10 nmol/min) was co-infused for 60 minutes.

\section{Blood assays}

After 30 minutes of supine rest, and before any drugs were administered, venous blood was withdrawn from the noninfused arm. Blood $(10 \mathrm{ml})$ was admixed with $1 \mathrm{ml}$ of $1 \%$ disodium EDTA and 1000 KIU aprotinin (Bayer AG, Leverkusen, Germany) for measuring plasma ET-1 and big ET-1. The sample was placed on ice and immediately centrifuged at $1500 \mathrm{~g}$ for 20 minutes. Plasma was frozen and stored at $-80^{\circ} \mathrm{C}$ until assayed. Following extraction using Bond Elut columns (Varian, Harbor City, California, USA), plasma concentrations of ET-1 (Peninsula Laboratories Europe Ltd, St Helens, UK), and big ET- 1 (Peninsula Laboratories Europe Ltd) were determined by radioimmunoassay as described previously. $^{30}$

\section{Statistical analysis}

FBF was expressed as $\mathrm{ml} / 100 \mathrm{ml}$ of tissue/min. ${ }^{31}$ Recordings from the first 60 seconds following wrist cuff inflation were not included in the analysis because of the variability in blood flow this produces. ${ }^{32}$ Usually, the final five flow recordings in each three minute measurement period were calculated and averaged for each arm. In order to reduce the variability of blood flow data, the ratio of flows in the two arms was calculated for each time point, thus using the non-infused arm as a contemporaneous control. ${ }^{33}$ The percentage change in FBF was calculated according to the formula:

\section{$\%$ change in $F B F=100 \times\left[\left(I_{t} / N_{t}\right)-\left(I_{b} / N_{b}\right)\right] /\left(I_{b} / N_{b}\right)$}

where $I_{t}$ and $N_{t}$ are FBFs in the infused and non-infused arms, respectively, at a given time point $(\mathrm{t})$ and $\mathrm{I}_{\mathrm{b}}$ and $\mathrm{NI}_{\mathrm{b}}$ are the FBFs at baseline (b); time 0 .
Table 2 Basal systemic haemodynamics and hormonal assays

\begin{tabular}{|c|c|c|c|}
\hline \multirow{2}{*}{$\begin{array}{l}\text { Variable } \\
\text { HR (beats/min) }\end{array}$} & \multicolumn{2}{|c|}{$\begin{array}{l}\text { Patients with } \\
\text { cirrhosis } \\
(\mathrm{n}=7)\end{array}$} & $\begin{array}{l}\text { Healthy } \\
\text { controls } \\
(n=7)\end{array}$ \\
\hline & 67 & (2) & $61 \quad(2)$ \\
\hline $\mathrm{MAP}(\mathrm{mm} \mathrm{Hg})$ & 85 & (5) & $90 \quad(2)$ \\
\hline $\mathrm{Cl}\left(\mathrm{l} / \mathrm{min} / \mathrm{m}^{2}\right)$ & 5.2 & $(0.4)^{* *}$ & $3.6(0.2)$ \\
\hline $\mathrm{SI}\left(\mathrm{ml} / \mathrm{m}^{2}\right)$ & 77 & $(6)^{*}$ & 58 (4) \\
\hline $\mathrm{SV}(\mathrm{ml})$ & 128 & (11) & 105 (8) \\
\hline TPVRI $\left(\mathrm{mm} \mathrm{Hg} / \mathrm{l} / \mathrm{min} / \mathrm{m}^{2}\right)$ & 17 & $(2)^{* *}$ & $25 \quad(2)$ \\
\hline \multicolumn{4}{|c|}{$\begin{array}{l}\mathrm{FBF}(\mathrm{ml} / 100 \mathrm{ml} \text { tissue } / \mathrm{min} \text { ) at } \\
\text { baseline } 1\end{array}$} \\
\hline Infused arm & 2.9 & $(0.4)$ & $3.1(0.2)$ \\
\hline Non-infused arm & 2.7 & (0.4) & $3.0(0.3)$ \\
\hline \multicolumn{4}{|c|}{$\begin{array}{l}\mathrm{FBF}(\mathrm{ml} / 100 \mathrm{ml} \text { tissue } / \mathrm{min}) \text { at } \\
\text { baseline } 2\end{array}$} \\
\hline Infused arm & 3.7 & $(0.5)$ & $3.7(0.4)$ \\
\hline Non-infused arm & 3.1 & (0.5) & $3.3(0.3)$ \\
\hline ET- 1 (pg/ml) & 3.3 & $(0.2)$ & $4.0(0.6)$ \\
\hline Big ET-1 (pg/ml) & 78 & (26) & $67 \quad(21)$ \\
\hline
\end{tabular}

Results are expressed as mean (SEM).

$E T-1$, endothelin-1; Cl, cardiac index; $F B F$, forearm blood flow; $H R$, heart rate; MAP, mean arterial pressure; SI, stroke index; SV, stroke volume; TPVRI, total peripheral vascular resistive index. Baseline 1, FBF before the "NO clamp" (end of phase 1). Baseline 2, FBF after adjusting the "NO clamp" and before infusion of $B Q-123$ (end of phase 3). ${ }^{*} p<0.05 ;{ }^{*} p<0.01$.

The percentage attenuation in area under the curve (AUC) was calculated according to the formula:

$$
\% \text { attenuation }=\left(\mathrm{AUC}_{\left[\mathrm{NOC}_{+}\right]}-\mathrm{AUC}_{\left[\mathrm{NOC}_{-}\right]}\right) /\left(\mathrm{AUC}_{\left[\mathrm{NOC}_{-}\right]}\right) \times 100
$$

where $[\mathrm{NOC}+]$ and [NOC-] are the presence or absence of the "NO clamp", respectively.

Data were expressed as mean (SEM) and examined by two way analysis of variance (ANOVA) for repeated measures or two tailed paired and unpaired Student's $t$ tests, as appropriate. A probability value of $p<0.05$ was taken to represent a statistically significant difference.

\section{RESULTS}

A summary of the subject characteristics at baseline is shown in table 1. Patients with cirrhosis were well matched to control subjects for age, sex, and body surface area although weight, and consequently body mass index (BMI), were significantly lower in the cirrhotic group $(\mathrm{p}<0.05)$. In addition, patients with cirrhosis and controls had a similar heart rate (HR) and MAP (table 2). In contrast, and despite a lower BMI, patients had higher SI $(p<0.05)$ and CI $(p<0.01)$, and lower TPVRI $(\mathrm{p}<0.01)$ (table 2$)$. Throughout each study there were no significant changes in MAP, HR, or FBF in the non-infused arm.

\section{Bilateral FBF}

There was no significant difference in baseline FBF between the infused and non-infused arm in each of the study groups. In addition, FBF after application of the "NO clamp" was, by design unchanged from baseline and was similar in both groups (table 2).

\section{Responses to L-NMMA infusion}

L-NMMA infusion significantly reduced FBF in patients with preascitic cirrhosis and in healthy controls $(p<0.001$, one way ANOVA $v$ baseline), the response reaching a plateau after 10 minutes of infusion. The response was similar in both groups, with blood flow in the infused arm reduced by 34 (5)\% and 35 (4)\% in cirrhotic patients, and by $30(2) \%$ and $29(4) \%$ in healthy controls, at 10 and 20 minutes, respectively. The dose of SNP required to restore baseline FBF was similar in patients 
- With NO clamp

- Without NO clamp

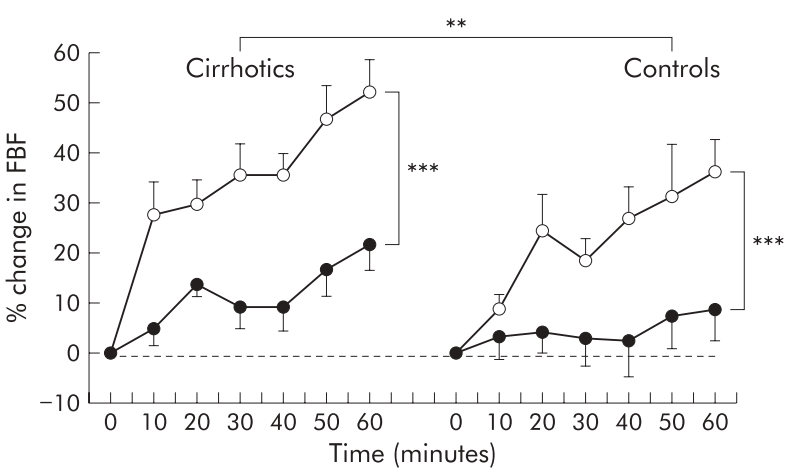

Figure 2 Percentage change in forearm blood flow (FBF) after $\mathrm{BQ}-123$ infusion (10 nmol/min for 60 minutes) in patients with cirrhosis and controls, with and without application of the "NO clamp". p $<0.001$ for each response except with "NO clamp" in controls (one way ANOVA). *** $p<0.001$ without "NO clamp" versus with "NO clamp" in patients with cirrhosis and controls (two way ANOVA with repeated measures); ${ }^{*} p<0.01$ patients versus controls with or without "NO clamp" (two way ANOVA with repeated measures).

with cirrhosis and controls (806 (140) and 811 (109) ng/min, respectively; $\mathrm{p}>0.05$ ).

Responses to BQ-123 infusion without the "NO clamp" $\mathrm{ET}_{\mathrm{A}}$ receptor antagonism, with BQ-123 infusion, increased FBF in both patients with cirrhosis and controls $(\mathrm{p}<0.001$, one way ANOVA for each group). Vasodilatation was significantly greater in patients with cirrhosis $(\mathrm{p}<0.001$, two way ANOVA with repeated measures) than controls. The maximum increase in FBF was $52(6) \%$ in patients, and 37 (6)\% in controls (fig 2).

\section{Responses to BQ-123 infusion during the "NO clamp"}

Application of the "NO clamp" significantly attenuated BQ-123 induced vasodilatation in both groups $(\mathrm{p}<0.001$, two way ANOVA versus responses to BQ-123 without the "NO clamp" for both groups). Indeed, in the control group, BQ-123 induced vasodilatation was abolished. However, BQ-123 infusion still caused significant vasodilatation in patients with cirrhosis, and this response was greater than in controls $(\mathrm{p}<0.01$, two way ANOVA $)$ : the maximum increase in FBF was $22(6) \%$ and $9(5) \%$, respectively (fig 2 ). The percentage attenuation in the area under the curve for BQ-123 induced vasodilatation due to application of the "NO clamp" was 66 (9)\% and $82(24) \%$ for patients and controls, respectively ( $\mathrm{p}>0.05$, unpaired $t$ test $)$.

\section{Blood assays}

As shown in table 2, basal plasma concentrations of ET- 1 and its biological precursor big ET-1 were similar in both groups.

\section{DISCUSSION}

These studies confirm our previous findings ${ }^{14}$ that patients with preascitic cirrhosis have an enhanced forearm vasodilatation to BQ-123 infusion, and the findings of others that these patients exhibit a normal forearm vasoconstriction to L-NMMA. In addition, they extend these observation $\mathrm{s}^{14}{ }^{15}$ by showing that NO substantially contributes to the vasodilatation response to BQ-123 in patients with cirrhosis as well as in healthy controls. Furthermore, these experiments show that there is a persistent vasodilatation in response to $\mathrm{BQ}-123$ during application of the "NO clamp" only in patients with cirrhosis. These results indicate a greater ET- 1 mediated tone in patients with preascitic cirrhosis, and suggest that the enhanced vasodilatation to $\mathrm{BQ}-123$ in these patients cannot be entirely attributed to increases in NO release but is likely to be directly related to an increase in ET-1 mediated tone. Alternatively, vasodilatation to BQ-123 in cirrhosis may be mediated by vasodilators other than $\mathrm{NO}$.

Due to its paracrine mode of action, the majority of ET- 1 is released abluminally to act on the adjacent vascular smooth muscle and endothelial cells ${ }^{34}$ and, as a consequence, plasma ET-1 concentrations may not truly reflect the underlying activity of the endothelin system. ${ }^{35}$ In the present study, we have confirmed our previous findings of normal plasma concentrations of ET- 1 and its biological precursor big ET- $1,{ }^{14}$ in association with functional abnormalities in the tonic activity of the endothelin system in patients with preascitic cirrhosis. The greater $\mathrm{ET}_{\mathrm{A}}$ mediated basal vascular tone in these patients reflects an increased local abluminal release of ET-1 and/or an enhanced $\mathrm{ET}_{\mathrm{A}}$ receptor coupling; through increased receptor numbers, affinity, or alterations of downstream events. Indeed, we have previously shown impaired FBF responses to exogenous ET-1 in a similar group of patients, ${ }^{14}$ which may also reflect a greater basal endogenous ET-1 activity, although receptor downregulation may also have a role.

The relationship between forearm vasodilatation to BQ-123 administration and endogenous NO production has previously been assessed in healthy control subjects using the "NO clamp" technique. ${ }^{15}$ The present study confirms that, after inhibition of endogenous nitric oxide production, there is a marked attenuation in the vasodilatation to $\mathrm{ET}_{\mathrm{A}}$ receptor antagonism in healthy volunteers, and extends these findings to patients with preascitic cirrhosis. Interestingly, the residual forearm vasodilatation to BQ-123 during the application of the "NO clamp" remained significantly greater in patients with cirrhosis

ET- 1 contributes to basal peripheral vascular tone through its actions on both $\mathrm{ET}_{\mathrm{A}}$ and $\mathrm{ET}_{\mathrm{B}}$ receptors. ${ }^{15}$ During $\mathrm{ET}_{\mathrm{A}}$ receptor antagonism, endogenous ET- 1 is able to act unopposed on the $\mathrm{ET}_{\mathrm{B}}$ receptor and may cause enhanced $\mathrm{ET}_{\mathrm{B}}$ mediated effects. The overall response to $\mathrm{ET}_{\mathrm{B}}$ receptor stimulation depends on the relative balance between the competing vasodilator and vasoconstrictor actions of the endothelial and vascular smooth muscle cell receptors, respectively. We have previously shown that infusion of $\mathrm{BQ}-788$, an $\mathrm{ET}_{\mathrm{B}}$ receptor antagonist, causes forearm arteriolar vasoconstriction in healthy subjects ${ }^{111415}$ and in patients with preascitic cirrhosis, ${ }^{14}$ and increases systemic vascular resistance in healthy subjects. ${ }^{36}$ These findings indicate that the overall balance of $\mathrm{ET}_{\mathrm{B}}$ mediated vascular tone favours vasodilatation. ${ }^{11}{ }^{14} 1536$ Therefore, the first potential mechanism underlying the enhanced vasodilatation in response to ET receptor antagonism could be greater $\mathrm{ET}_{\mathrm{B}}$ mediated release of vasodilators, other than NO, such as prostacyclin, endothelium derived hyperpolarising factor, or cannabinoid agonists. ${ }^{37-39}$ The second explanation is that $\mathrm{ET}_{\mathrm{x}}$ receptor antagonism inhibits endothelial NOS or NO generation. However, given that the $\mathrm{ET}_{\mathrm{A}}$ receptor is not expressed on the endothelium, any effect on endothelial NOS or NO generation must be indirect and mediated by as yet unknown pathways.

The substantial vasoconstriction produced by infusion of L-NMMA, a specific inhibitor of NOS, in the studied groups confirms the role of endogenous NO release in the maintenance of basal peripheral vascular tone in both healthy humans ${ }^{202140}$ and patients with early ${ }^{21} 40$ and advanced cirrhosis. ${ }^{26}$ The similarity of the L-NMMA mediated vasoconstrictor response in both groups is in keeping with the results of previous studies in similar groups of patients, ${ }^{21}{ }^{40}$ and argues against a greater basal NOS activity in the peripheral arterioles of patients with well compensated cirrhosis. Moreover, the proportionate reduction in BQ-123 induced vasodilatation by the application of the "NO clamp" was similar in both groups. This suggests that inhibition of the endothelin system does 
not enhance basal NO release in patients with preascitic cirrhosis. However, the similarity in the responses to L-NMMA in both groups does not preclude NO playing a role in the hyporesponsiveness to vasopressors in cirrhosis. Indeed, in many conditions, the basal release of NO is unchanged but the stimulated release of NO is impaired. For example, in patients with hypercholesterolaemia, the paradigm of endothelial dysfunction, the response to L-NMMA infusion is normal but the response to the endothelial cell stimulant acetylcholine is markedly impaired. ${ }^{41}{ }^{42}$

Total blood volume is expanded in patients with compensated cirrhosis. ${ }^{43}$ In the present study, supine patients had portal hypertension and an elevated cardiac index. This is consistent with the previous findings of an increased CI in patients with compensated cirrhosis that occurs before a reduction in systemic vascular resistance, ${ }^{44}$ and appears to be primarily related to a greater than normal increase in supine induced cardiac preload. Moreover, the presence of a hyperdynamic circulation (increased CI and decreased systemic vascular resistance) has previously been shown in patients with preascitic cirrhosis, ${ }^{45-47}$ particularly in the supine position. ${ }^{45} 46$ However, some studies do not show hyperdynamic changes in patients with preascitic cirrhosis, but we suspect this is a reflection of the difference in posture, portal pressure, and portosystemic shunting.

Although differences in cardiac output and circulating blood volume may influence responses to drugs in systemic studies, this should not be relevant here. Agents were infused at doses with a local, not systemic, effect and were given into a similar FBF in patients and controls. Hence drug exposure should be similar in both groups.

One might suggest that the mild cholestasis observed in three patients with primary biliary cirrhosis could influence the results of this study. Indeed, marked cholestasis can alter the vascular responses to exogenous vasopressor agents. However, we believe that this was not the case in the present study because the mean plasma bilirubin concentration of the patients included was $28 \mu \mathrm{mol} / \mathrm{l}$ (table 1), and only two of the patients, with early Child grade B cirrhosis, had bilirubin concentrations $>34 \mu \mathrm{mol} / \mathrm{l}$. In addition, we included similar patients with primary biliary cirrhosis in our previous studies, and showed normal vascular responses to noradrenaline infusion alongside impaired responses to angiotensin II. $^{28}$ The normal response to noradrenaline indicates that vascular reactivity is unaffected by mild cholestasis at this early stage of cirrhosis and argues against a significant contribution of cholestasis to the vascular reactivity described in the present study.

In summary, this study confirms that patients with preascitic cirrhosis have enhanced forearm vasodilator responses to selective $\mathrm{ET}_{\mathrm{A}}$ receptor antagonism and normal vasoconstrictor responses to L-NMMA. In addition, we have demonstrated that the application of the "NO clamp" substantially attenuates the BQ-123 induced vasodilatation in both healthy volunteers and patients with cirrhosis, although the vasodilatation remained greater in patients. These findings suggest that, in patients with cirrhosis, NO is not the sole mediator of the enhanced vasodilatation response to $\mathrm{ET}_{\mathrm{A}}$ receptor antagonism, and that $\mathrm{ET}_{\mathrm{A}}$ receptor mediated peripheral vascular tone is enhanced independent of the L-arginine:NO pathway.

\section{ACKNOWLEDGEMENTS}

A Helmy is a recipient of an Egyptian Government Scholarship. DJ Webb was supported by a Wellcome Trust Research Leave Fellowship (WT 0526330) at the time this work was performed. This project was supported by a grant from the Sir Stanley and Lady Davidson Fund. We thank Neil Johnston (Clinical Pharmacology Unit, Western General Hospital, Edinburgh) for performing the hormone assays.

\section{Authors' affiliations}

A Helmy, Liver Unit, Department of Medicine, Royal Infirmary of Edinburgh, Edinburgh, UK, and Clinical Pharmacology Unit and Research Centre, Department of Medical Sciences, University of Edinburgh, Western General Hospital, Edinburgh, UK

D E Newby, Department of Cardiology, Royal Infirmary of Edinburgh, Edinburgh, UK

R Jalan*, P C Hayes, Liver Unit, Department of Medicine, Royal Infirmary of Edinburgh, Edinburgh, UK

D J Webb, Clinical Pharmacology Unit and Research Centre, Department of Medical Sciences, University of Edinburgh, Western General Hospital, Edinburgh, UK

*Present address: Institute of Hepatology, Royal Free and University College Medical School, Harold Samuel House, 69-75 Chenies Mews, London WC1E 6HX, UK

\section{REFERENCES}

1 Murray JF, Dawson AM, Sherlock S. Circulatory changes in chronic liver disease. Am J Med 1958:32:358-67.

2 Kontos HA, Shapiro W, Mauck HP, et al. General and regional circulatory alterations in cirrhosis of the liver. Am J Med 1964;37:526-35

3 Kowalski HJ, Abelmann WH. The cardiac output at rest in Laennec's cirrhosis. J Clin Invest 1953;32:1025-33.

4 Braillon A, Cales P, Valla D, et al. Influence of the degree of liver failure on the systemic and splanchnic haemodynamics and on the response to propranolol in patients with cirrhosis. Gut 1986;27:1206-9.

5 Schrier RW, Arroyo V, Bernardi M, et al. Peripheral arterial vasodilation hypothesis: a proposal for the initiation of renal sodium and water retention in cirrhosis. Hepatology 1988;8:1151-7.

6 Yanagisawa $M$, Kurihara $\mathrm{H}$, Kimura $\mathrm{S}$, et al. A novel potent vasoconstrictor peptide produced by vascular endothelial cells. Nature 1988:332:411-15.

7 Arai H, Hori S, Aramori l, et al. Cloning and expression of a cDNA encoding an endothelin receptor. Nature 1990;348:730-2.

8 Sakurai T, Yanagisawa M, Takuwa Y, et al. Cloning a cDNA encoding non- isopeptide-selective subtype of the endothelin receptor. Nature 1990;348:732-5.

9 Spokes RA, Ghatei MA, Bloom SR. Studies with endothelin-3 and endothelin- 1 on rat blood pressure and isolated tissues: evidence for endothelin receptor subtypes. J Cardiovasc Pharmacol 1989;13:S191-2.

10 Davenport AP, O'Reilly G, Kuc RE. Endothelin $\mathrm{ET}_{A}$ and $\mathrm{ET}_{B}$ mRNA and receptors expressed by smooth muscle in the human vasculature: majority of the ET subtype. BrJ Pharmacol 1995:114:1110-6.

11 Haynes WG, Strachan FE Webb DJ. Endothelin $E_{A}$ and $E_{B}$ receptors cause vasoconstriction in human resistance and capacitance vessels in vivo. Circulation 1995;92:357-63.

12 Davenport AP, Maguire JJ. Is endothelin-induced vasoconstriction mediated only by $\mathrm{ET}_{\mathrm{A}}$ receptors in humans? Trends Pharmacol Sci 1994;15:9-11.

13 Takayanagi R, Kitazumi K, Takasaki C, et al. Presence of a non-selective type of endothelin receptor on vascular endothelium and its linkage to vasodilatation. FEBS Lett 1991;282:103-6.

14 Helmy A, Jalan R, Newby DE, et al. Altered peripheral vascular responses to exogenous and endogenous endothelin- 1 in patients with well-compensated cirrhosis. Hepatology 2001;33:826-31.

15 Verhaar MC, Strachan FE, Newby DE, et al. Endothelin-A receptor antagonist- mediated vasodilatation is attenuated by inhibition of nitric oxide synthesis and by endothelin-B receptor blockade. Circulation 1998;97:752-6.

16 Berrazueta JR, Bhagat K, Vallance $P$, et al. Dose- and time-dependency of the dilator effects of the endothelin antagonist, $B Q-123$, in the human forearm. Br J Clin Pharmacol 1997;44:569-71.

17 Martin P. Gines P. Schrier RW. Nitric oxide as a mediator of haemodynamic abnormalities and sodium and water retention in cirrhosis. N Engl J Med 1998;339:533-41.

18 Howes LG, Reid JL. Decreased vascular responsiveness to noradrenaline following regular ethanol consumption. $\mathrm{Br} J$ Clin Pharmacol 1985;20:669-74.

19 Rankin LI, Luft FC, Henry DP, et al. Sodium intake alters the effects of noradrenaline on blood pressure. Hypertension 1981:3:650-6.

20 Hashimoto M, Akishita M, Eto M. Modulation of endothelium-dependent flow- mediated dilatation of the brachial artery by sex and menstrual cycle. Circulation 1995;92:3431-5.

21 Spratt JC, Goddard J, Patel N, et al. Systemic ETA receptor antagonism with BQ-123 blocks ET-1 induced forearm vasoconstriction and decreases peripheral vascular resistance in healthy men. $\mathrm{Br} J$ Pharmacol 2001;134:648-54.

22 Vallance $\mathbf{P}$, Collier J, Moncada S. Effects of endothelium-derived nitric oxide on peripheral arteriolar tone in man. Lancet 1989;28:997-1000.

23 Calver A, Harris A, Maxwell JD, et al. Effect of local inhibition of nitric oxide synthesis on forearm blood flow and dorsal hand vein size in patients with alcoholic cirrhosis. Clin Sci 1994:86:203-8.

24 Appel PL, Kram HB, Mackabee J, et al. Comparison of measurements of cardiac output by bioimpedance and thermodilution in severely ill surgical patients. Crit Care Med 1986;14:933-5 
25 Northridge DB, Findlay IN, Wilson J, et al. Non-invasive determination of cardiac output by Doppler echocardiography and electrical bioimpedance. Br Heart J 1990;63:93-7.

26 Wiinberg N, Walter-Larsen S, Eriksen C, et al. An evaluation of semi-automatic blood pressure manometers against intra-arterial blood pressure. J Amb Monit 1988;1:303-9.

27 Newby DE, Jalan R, Masumori S, et al. Peripheral vascular tone in patients with cirrhosis: role of the renin-angiotensin and sympathetic nervous system. Cardiovasc Res 1998;38:221-8.

28 Helmy A, Jalan R, Newby DE, et al. Role of angiotensin II in regulation of basal and sympathetically stimulated vascular tone in patients with early and advanced cirrhosis. Gastroenterology 2000;1 18:565-72.

29 Stroes ESG, Luscher TF, deGroot FG, et al. Cyclosporin A increases nitric oxide activity in vivo. Hypertension 1997;29:570-5.

30 Rolinski B, Sadri I, Bogner J, et al. Determination of endothelin-1 immunoreactivity in plasma, cerebrospinal fluid and urine. Res Exp Med 1994; 194:9-24.

31 Whitney RJ. The measurement of volume changes in human limbs. J Physiol (London) 1953;121:1-27.

32 Kerslake DM. The effect of the application of an arterial occlusion cuff to the wrist on the blood flow in the human forearm. J Physiol (London) 1949;108:451-7.

33 Benjamin N, Calver A, Collier J, et al. Measuring forearm blood flow and interpreting the responses to drugs and mediators. Hypertension 1995:25:918-23.

34 Hocher B, Thone-Reineke C, Baver C, et al. The paracrine endothelin system: pathophysiology and implications in clinical medicine. Eur J Clin Chem Clin Biochem 1997;35:175-89.

35 Frelin C, Guedin D. Why are circulating concentrations of endothelin-1 so low? Cardiovasc Res 1994;28:1613-22.

36 Strachan FE, Spratt JC, Wilkinson IB, et al. Systemic blockade of the endothelin-B receptor increases peripheral vascular resistance in healthy man. Hypertension 1999;33:581-5.
37 De Nucci G, Thomas R, D'Orleans-Juste P, et al. Pressor effects of circulating endothelin are limited by its circulation and by the release of prostacyclin and endothelium-derived relaxing factor. Proc Natl Acad Sci U S A 1988;85:9797-800.

38 Barriere E, Tazi KA, Rona JP, et al. Evidence for an endothelium-derived hyperpolarizing factor in the superior mesenteric artery from rats with cirrhosis. Hepatology 2000;32:935-41.

39 Batkai S, Jarai Z, Wagner JA, et al. Endocannabinoids acting at vascular $\mathrm{CB} 1$ receptors mediate the vasodilated state in advanced liver cirrhosis. Nat Med 2001:7:827-32.

40 Ryan J, Jennings G, Dudley F, et al. Smooth muscle-derived nitric oxide is elevated in isolated forearm veins in human alcoholic cirrhosis. Clin $\mathrm{Sci}_{\mathrm{i}}$ 1996;91:23-8

41 Chowienczyk PJ, Watts GF, Cockcroft JR, et al. Impaired endothelium-dependent vasodilatation of forearm resistance vessels in hypercholesterolaemia. Lancet 1992;340: 1430-32.

42 Stroes ES, Koomans HA, de Bruin TWA, et al. Vascular function in the forearm of hypercholesterolaemic patients off and on lipid-lowering medication. Lancet 1995;346:467-71.

43 Wong F, Liu P, Tobe S, et al. Central blood volume in cirrhosis: measurement with radionuclide angiography. Hepatology 1994;19:312-21

44 Lewis FW, Adair O, Rector WG. Arterial vasodilatation is not the cause of increased cardiac output in cirrhosis. Gastroenterology 1992:102:1024-9.

45 Gentilini P, Romanelli RG, Laffi G, et al. Cardiovascular and renal function in normotensive and hypertensive patients with compensated cirrhosis: effects of posture. J Hepatol 1999;30:632-8.

46 Bernardi M, Di Marco C, Trevisani F, et al. The haemodynamic status of pre-ascitic cirrhosis: an evaluation under steady state condition and after postural change. Hepatology 1992;16:341-6.

47 Maroto A, Gines P, Arroyo V, et al. Brachial and femoral artery blood flow in cirrhosis: relationship to kidney dysfunction. Hepatology 1993; 17:788-93. 